\section{Abstract} 3376157.

\title{
The biological effects of antidepressants on the Molluscs and Crustaceans: A Review
}

Peter P. Fong ${ }^{1 *}$, Alex T Ford ${ }^{2}$

${ }^{1}$ Department of Biology, Gettysburg College, 300 N. Washington St., Gettysburg, PA 17325, USA

${ }^{2}$ Institute of Marine Sciences, School of Biological Sciences, University of Portsmouth, Ferry Road, Portsmouth, PO4 9LY

*Corresponding author. email: pfong@gettysburg.edu: Tel.: +1 717337 6154; fax: +1 717

Keywords: SSRIs, pharmacetuicals; invertebrates; ecotoxicology; pollution; neuroendocrine

Antidepressants are among the most commonly detected human pharmaceuticals in the aquatic environment. Since their mode of action is by modulating the neurotransmitters serotonin, dopamine, and norepinephrine, aquatic invertebrates who possess transporters and receptors sensitive to activation by these pharmaceuticals are potentially affected by them. We review the various types of antidepressants, their occurrence and concentrations in aquatic environments, and the actions of neurohormones modulated by antidepressants in molluscs and crustaceans. Recent studies on the effects of antidepressants on these two important groups show that molluscan reproductive and locomotory systems are affected by antidepressants at environmentally relevant concentrations. In particular, antidepressants affect spawning and larval release in bivalves and disrupt locomotion and reduce fecundity in snails. In crustaceans, antidepressants affect freshwater amphipod activity patterns, marine amphipod photo- and geotactic behavior, crayfish aggression, and daphnid reproduction and development. We note with interest the occurrence of non-monotonic dose responses curves in many studies on effects of antidepressants on aquatic animals, often with effects at low concentrations, but not at higher concentrations, and we suggest future experiments consider testing a broader range of concentrations. Furthermore, we consider invertebrate immune responses, genomic and transcriptomic sequencing of invertebrate genes, and the ever-present and overwhelming question of how contaminant mixtures could affect the action of neurohormones as topics for future study. In addressing the question, do antidepressants $\underline{\text { affect aquatic invertebrates at concentrations currently found in the environment, there is }}$ strong evidence to suggest the answer is yes. Furthermore, the examples highlighted in this 


\section{Antidepressants in the aquatic environment}

\section{a. Background}

The release of human pharmaceuticals and personal care products into aquatic ecosystems continues to be a serious environmental problem. There is a staggering list of prescription drugs passed from humans to wastewater treatment plants and into receiving streams, estuaries, or oceans by direct consumption, metabolism, and excretion or by toilet flushing of old prescriptions, that have been detected in water, sediment, and organisms. Environmental scientists and aquatic toxicologists have been aware of the problem since the 1970-80's (Hignite and Azarnoff, 1977; Richardson and Bowron, 1985), but starting in the late 1990's concern over the problem became more intensified. In 1999, a seminal paper by Daughton and Ternes brought the problem of pharmaceutical and personal care product pollution to the forefront of aquatic research and set into motion studies in the current fields of fate, effects, and assessments of such pharmaceutical pollution. Thus, there has been a growing number of studies addressing effects of human pharmaceuticals on aquatic animals. There are excellent reviews by Kummerer, 2008; Daughton and Brooks, 2011; Boxall et al., 2012; Brausch et al., 2012; Brooks and Huggett, 2012.

While there are literally hundreds of human pharmaceuticals excreted and which end up in the aquatic environment, those that are destined to have an effect on the physiology of aquatic invertebrates are ones that would interact with evolutionarily well conserved transporter and receptor proteins. Furthermore, there are model organisms whose physiological systems and their regulation by such proteins are well understood. Since molluscs such as the sea hare Aplysia and crustaceans like crayfish have been model organisms in neurophysiological research for decades, these systems and the drugs that modulate them are well understood. Human antidepressants are widely prescribed drugs throughout the developed world and their mode of action is by modulating neurotransmission in the human brain. But in addition, early laboratory studies (Kulkarni et al., 1992; Sarojini et al., 1993) showed that some antidepressants have an effect on critical invertebrate physiological functions such as ovarian and testicular growth.

In this paper we review the modulatory effects of antidepressants on various physiological systems in molluscs and crustaceans, two groups of aquatic invertebrates that are numerically dominant and speciose, and thus ecologically important. We review the data on environmental concentrations of antidepressants, link this information with the known action of neurohormones, 
discuss recent studies showing effects of antidepressants on molluscs and crustaceans, and suggest important questions for future research.

\section{b. Types of antidepressants}

There are several different types of antidepressants from tricyclics like imipramine and chlomipramine which block serotonin and norepinephrine reuptake transporters to monoamine oxidase inhibitors which blocks the enzyme that digests neurotransmitters such as serotonin and dopamine. By far the most widely prescribed antidepressants in are selective serotonin reuptake inhibitors (SSRIs) such as Prozac (fluoxetine) and Zoloft (sertraline) and selective serotonin-norepinephrine reuptake inhibitors (SSNRIs) such as Effexor (venlafaxine) and Cymbalta (duloxetine). The mode of action of SSRIs and SSNRIs is similar to that of tricyclics in that they bind to and inhibit pre-synaptic reuptake transport proteins. These proteins normally recycle neurotransmitters back into the pre-synaptic terminal. Inhibition of these transporters allows neurotransmitters to remain in the synaptic cleft longer. Thus, all of the aforementioned antidepressants work by modulation of serotonergic, dopaminergic, or noradrenergic neurotransmission. Because SSRIs and SSNRIs are the most widely prescribed antidepressants, they are the most commonly detected in samples of wastewater influent, effluent, raw sewage, and downstream from treatment plants. The vast majority of published studies on the effects of antidepressants on molluscs and crustaceans have utilized these antidepressants.

\section{c. Concentrations in the aquatic environment.}

Within the last decade, a large number of studies have measured active pharmaceutical ingredients (APIs) in various aquatic systems worldwide. Studies of measured pharmaceutical concentrations include those from freshwater (Kolpin et al., 2002), from estuaries (Thomas and Hilton, 2004; Roberts and Thomas, 2006; Benotti and Brownawell, 2007; Madureira et al., 2010), in the open ocean (Choong et al. 2006; Pait et al., 2006), in drinking water (Zwiener, 2007), and biosolids (Jones-Lepp and Stevens, 2007). There are some excellent reviews by Calisto and Estevez (2009), Pai et al., (2010), and Santos et al., (2010).

Not surprisingly, antidepressants were among the myriad of pharmaceuticals detected at measureable concentrations. Historically, fluoxetine was the most commonly detected 
antidepressant in wastewater. Kolpin et al., (2002) measured fluoxetine at $0.012 \mu \mathrm{g} / \mathrm{L}$ downstream from wastewater treatment plants and from livestock production facilities in the United States. Their study was one of the first large scale studies of API contamination in North America. However. their measured concentrations for fluoxetine were lower than those reported by Weston et al., (2001) of from 0.32 to $0.54 \mu \mathrm{g} / \mathrm{L}$ in municipal effluent and surface waters and $0.509 \mu \mathrm{g} / \mathrm{L}$ in Canadian wastewater effluent (Chen et al. 2006).

Sertraline is the active ingredient in the antidepressant Zoloft and is one of the most commonly prescribed antidepressants in the world (Schultz et al., 2010). It has been measured at concentrations similar to fluoxetine. The highest environmental concentrations of sertraline measured to date have been reported from raw sewage in Norway at $0.0084 \mu \mathrm{g} / \mathrm{L}$ Vasskog et all, (2006), in Canada at $0.006 \mu \mathrm{g} / \mathrm{L}$ and in Canadian effluent at $0.005 \mu \mathrm{g} / \mathrm{L}$ (Lajeunesse et al.,2008).

In recent years, the SSNRI venlafaxine and SSRI citalopram have surpassed fluoxetine as the antidepressant occurring in the highest environmental concentrations. These antidepressants have been measured at concentrations up to 10X higher than any for fluoxetine. Lajeunesse et al., (2008) measured venlafaxine concentrations from Canadian treatment plants of from $0.195-0.213 \mu \mathrm{g} / \mathrm{L}$ in raw sewage, $0.176-0.214$ in effluent and $0.013-0.045$ in receiving streams flowing into the St. Lawrence River. In the same year Schultz and Furlong (2008) measured venlafaxine at $2.19 \mu \mathrm{g} / \mathrm{L}$ in wastewater effluent in Minnesota and at $1.31 \mu \mathrm{g} / \mathrm{L}$ downstream from treatment plants in Texas. These are the highest environmental concentrations reported for any antidepressant. Later, Schultz et al. (2010) published mean concentrations of venlafaxine from Boulder Creek, Colorado as high as $0.22 \mu \mathrm{g} / \mathrm{L}$. Metcalfe et al. (2010) measured mean concentrations of venlafaxine $>1.0 \mu \mathrm{g} / \mathrm{L}$ in raw wastewater and $0.5 \mu \mathrm{g} / \mathrm{L}$ at sampling sites 10 meters downstream from the treatment plant in the Grand River watershed of southern Ontario.

For citalopram, Lajeunesse et al., (2008) reported concentrations of $0.052 \mu \mathrm{g} / \mathrm{L}$ in raw sewage, 0.057 in effluent, and $0.011 \mu \mathrm{g} / \mathrm{L}$ in receiving water. It has been measured as high as $0.07 \mu \mathrm{g} / \mathrm{L}$ in American wastewater effluent by Schultz et al., (2010). Metcalfe et al., (2010) reported higher mean concentrations of citalopram in raw Canadian wastewater (approximately $0.25 \mu \mathrm{g} / \mathrm{L}$ ) and 10 meters downstream (approximately $0.125 \mu \mathrm{g} / \mathrm{L}$ ). Styrishave et al., (2011) measured concentrations of citalopram in raw wastewater from 0.19 $-10.3 \mu \mathrm{g} / \mathrm{L}$ in a Danish treatment plant.

While the antidepressants mentioned above are indicated for the treatment of anxiety, panic disorder, and obsessive-compulsive disorder to name a few, and all work by 


\section{Overview of neurohormones impacted by antidepressants}

\section{8a. Mollusca:} junction) and Birmingham and Tauck, 2006 (on neuromodulation). precursors, 5-HTP and DOPA, respectively.

modulation of the neurotransmitters serotonin, dopamine, and norepinephrine at the presynaptic terminal, these drugs can have multiple biological effects in humans such as weight gain, fatigue, and sexual dysfunction. Furthermore, since the genes for the reuptake transporters and/or receptors undoubtedly evolved in invertebrates such as molluscs and crustaceans, and quite possibly even in plants (e.g. serotonin and dopamine are both widely distributed in plants), release of drugs designed to modulate evolutionarily ancient neurotransmitters would be expected to have multiple biological effects on these organisms.

$$
\text { A thorough review of the roles of neurohormones in the regulation of physiological and }
$$
behavioral mechanisms in molluscs encompasses research from more than 50 years ago, and thus goes well beyond the scope of this paper. We present here a cursory look at some of the physiological systems that are regulated by two principal biogenic monoamines, serotonin and dopamine. There are excellent reviews by Weiger, 1997 (on behavior), Dayan and Huys, 2009; $\mathrm{Wu}$ and Cooper, 2012 (on receptors and synaptic transmission at neuromuscular

A number of studies have shown serotonergic and dopaminergic regulation of locomotion in gastropods. It has been known for decades that serotonin has cilioexcitatory properties (Gosselin, 1961). Serotonin controls pedal ciliary activity in marine snails, such as Tritonea diomedea (Audesirk et al., 1979) and freshwater snails, Lymnaea stagnalis (Syed and Winlow, 1989) and Planorbis corneus (Deliagina and Orlovsky, 1990). Serotonin also controls pedal muscle contractions and it has been shown to regulate swimming in the nudibranch Melibe leonine (Lewis et al. 2011). In land snails, Helix lucorum, serotonin accelerates locomotion and stimulates crawling while dopamine causes muscular contractions of the foot regulating its length (Pavlova, 2001). Dopamine antagonists cause "sole detachment" in Helix by causing the lateral edge of the foot to lift off of the substrate (Sakharov and Salanki (1982). Tsyganov and Sakharov (2000) found that fictive muscular locomotion in L. stagnalis could be induced by both serotonin and dopamine as well as their

While locomotion is limited in most bivalves, serotonin activates structures similar to those it activates in gastropods. Serotonin regulates the gill ciliary activity in mussels and 
oysters (Aiello, 1970, Saimi et al. 1983) and increases both the ciliary activity and diameter of gill ostia in zebra mussels (Gardiner et al., 1991). When zebra mussel siphons and adjacent mantle tissue are exposed to high $(1 \mathrm{mM})$ concentrations of serotonin, the siphons open and the muscles contract, but at low $(1 \mu \mathrm{M})$ concentrations the muscles relax (Ram et al. 1999).

Serotonin regulates several reproductive processes in bivalves. Serotonin receptors have been identified on egg cell membranes (Krantic et al. 1991, Guerrier et al. 1996) and serotonin has been detected in bivalve ovaries by immunocytochemistry and HPLC (Ram et al. 1992). Oocyte maturation and germinal vesicle breakdown (GVBD) can be induced in a number of different bivalve species by serotonin and its receptor ligands (Osanai and Kuraishi, 1988, Hirai et al. 1988, Kadam and Koide, 1989, Fong et al. 1994). Because of its importance in aquaculture, the induction of spawning in bivalves has been well studied. Serotonin and its receptor ligands induce spawning in both marine (Matsutani and Nomura, 1982, Gibbons and Castagna, 1984) and freshwater (Ram et al. 1993) bivalves. Furthermore, it induces spawning in species that release oocytes arrested at prophase I (Spisula spp.) or metaphase I (Dreissena polymorpha). In the live bearing, freshwater fingernail clams, serotonin induces parturition (Fong and Warner, 1995). Recently Meechonkit et al. (2012) showed that exposure of the freshwater mussel Hyriopsis bialatus to different concentrations of serotonin significantly induced release of viable glochidia which developed normally. While dopamine has been detected in bivalve gonads (Osada and Nomura 1989), its role in regulating reproductive processes is unclear. However, dopamine has been shown to reduce the intensity of serotonin-induced spawning in zebra mussels (Fong et al. 1993a).

In freshwater gastropods, serotonin regulates several reproductive processes. In Lymnaea stagnalis, a serotonin receptor (5-HTLym) binds several serotonin receptor ligands with high affinity (Sugamori et al., 1993). Bath-applied serotonin induces the contraction of the penis retractor muscle thus it is likely involved with penis withdrawl (Croll et al. 1991). Furthermore, the penis nerve in L. stagnalis produces 8 neuropeptides as well as serotonin. By contrast, a serotonin receptor antagonist, methiothepin induces the eversion of the preputium containing the penis, but reduces egg laying and copulatory behavior in the snail Biomphalaria glabrata (Muschamp and Fong, 2001). Earlier studies by Manger et al. (1996) showed that B. glabrata, exposure to serotonin increased ovulation and oviposition in mature snails (Manger et al., 1996). Serotonin-induced rotation of embryos within egg capsules has 


\section{2b. Crustacea}

been shown by Diefenbach et al.,(1991) in the freshwater snail Helisoma trivolvis. The rotation is cilia driven and postulated to increase oxygen availability in embryos during periods of low oxygen. Recently, Shartau et al., (2010) showed that embryos exposed to serotonin lived $>2 \mathrm{x}$ as long as untreated embryos subjected to anoxia. Filla et al., (2009) showed that in the embryonic development of L. stagnalis, both dopamine and its synthesizing enzyme increase continuously, whereas levels serotonin remained low. However both serotonin and dopamine enhanced embryonic rotation.

The veliger larvae of some marine snails (Ilyanassa obsoleta) contain a large number serotonergic and dopaminergic neurons. When exposed to exogenous serotonin the larvae undergo metamorphose (Couper and Leise, 1996). In the nudibranch Phestilla sibogae, competent larvae metamorphose when exposed to a factor from their bryozoan prey. Treatment of larvae with the dopamine precursor, L-Dopa increases dopamine concentration, and potentiated the frequency of larval metamorphosis when exposed to low concentrations of the natural inducer.

Neurohormones control a wide variety of biological systems within the Crustacea including: reproduction, growth, maturation, larval development, immune function; metabolism, behaviour and colour physiology (Diwan, 2005; Fingerman, 1997; Fingerman, 1987; Sarojini et al 1995; Huber et al 1997; Cheng et al 2006; Li et al 2005; Fingerman, 1983). For example, both serotonin and dopamine has been found to stimulate the release of multiple other crustacean hormones including hyperglycaemic hormone, red and blackpigment dispersing/concentrating hormone, neurodepressing hormone, moult-inhibiting hormone and gonad stimulating hormone (see Fingerman, 1997; Chen et al 2003; Wongprasert et al 2006; and papers within), Consequently, any chemicals in the environment that have the ability to modulate these hormones conceivably have the ability to disrupt the normal endocrine and biological function in exposed organisms in a vast number of ways. Pasztor and MacMillan (1990) reported in a study of the crayfish, Cherax destructor and the lobster, Homarus americanus that some instances neurohormones that have excitatory responses whereas in other species may be ineffective or depressive. Therefore, those wishing to extrapolate the roles and effects of exogenous neurological modulators in one species may find it more difficult to discern those occurring in other species. Here we provide an overview 
and examples of the different functions some neurohormones linked to antidepressant function.

The roles of serotonin, dopamine and octopamine have attracted a lot of attention within the aquaculture sciences for their potential to speed up growth, maturation and spawning (Diwan, 2005; Wongprasert et al. 2006). The results of which has considerably increased our understanding of crustacean endocrinology. For example, Wongprasert et al (2006) reported that the black tiger shrimp Penaeus monodon, when injected with serotonin (5Hydroxytryptamine, 5HT) developed its ovary at a similar rate to unilateral eyestalk ablated shrimp. In addition, the authors reported that the hatching rate and the amount of nauplii produced per spawner were also significantly higher in 5HT injected shrimp. Similar results have been observed for the crayfish Procambarus clarkia, the white Pacific shrimp Litopanaeus vannamei, the freshwater giant prawn, Macrobrachium rosenbergii, the fiddler crab Uca pugilator (Vacu and Alfaro, 2000; Chen et al 2005; Sarojini et al 1995). Conversely, Chen et al (2003) has shown that dopamine is able to inhibit the ovarian maturation and Sarojini et al. (1995) found that dopamine has a dose dependant inhibitory effect on the testicular maturation.

Crustacean biologists have long established links between serotonin levels and changes in behaviour amongst the Crustacea. For example, during daylight hours the common shore crab Carcinus maenas are strongly photonegative. McPhee and Wilkens (1989) found that during daylight they spent around $76 \%$ of their time hidden under rocks or buried in sand. However, when crabs were injected with serotonin this photonegative behaviour was reduced and the crabs spent only $32 \%$ of their time hidden or buried. Serotonin is also known to affect phototaxis and geotaxis behaviour in amphipods (Tain et al., 2006). Acanthocephalan and trematode parasites have the ability to modify amphipod phototactic and geotactic behaviour as a means of increasing their likelihood of being eaten by their definitive hosts (Bauer et al., 2005, Bethel and Holmes, 1973, Lagrue et al., 2007, Cezilly et al., 2000). Tain et al. (2006) has shown that infection with acanthocephalan parasites is associated with increased brain serotonergic activity which instigates the behaviour alterations. Work by Guler and Ford (2010) recently established that serotonin altering parasites, serotonin and the anti-depressant drug fluoxetine can significantly affect the phototaxis and geotaxis behaviour of amphipods at concentrations as low as $10 \mathrm{ng} / \mathrm{l}$. Recently Perrot-Minnot et al (2013) recently provided 
some evidence for the role of 5HT receptors in modulating phototaxis behaviour specifically highlighting 5-HTR2 subtype.

In decapod crustaceans, serotonin has been suggested to serve important roles in mediating aggressive behaviours (Huber et al 1997a; Huber and Delago 1998. Sneddon et al 2000). Doernberg et al (2001) investigated the role(s) of serotonin in the fighting behaviour of lobsters, Homarus americanus. In some individuals, 5,7-dihydroxytryptamine (neurotoxin) was injected in order to deplete the animals of serotonin in their nervous tissue. They found that the treated animals showed an increased tendency to engage in agonistic encounters. This result was similar to the lobsters that had been injected with serotonin. Therefore, the authors concluded that either high or low levels of serotonin increased the tendency of lobsters to engage in fights. In crayfish, Astacus astacus, Huber and Delago (1998) noted that if the animals were injected with serotonin then the fighting behaviour altered and the fights lasted considerably longer.

The immune systems of crustaceans are also known to be influenced by neurohormones. For example, Li et al (2005) injected the freshwater giant prawn Macrobrachium rosenbergii with dopamine at a range of concentrations and recorded biomarkers relating to immune function. The study reported that a wide variety of immune parameters were impacted through dopamine (DA) injection. Interestingly, the authors also observed an increased mortality in DA treated $M$. rosenbergii when challenged with the bacterial pathogen, supporting the evidence for a reduced immune function. Reduced immune function has also been found in white shrimp Litopanaeus vannamei across a range of immune parameters measured (Chen et al 2006). Similarly, when challenged with a bacterial pathogen increased mortality was observed in noradrenaline (norepinephrine) injected individuals than controls (Chen et al 2006).

The regulation of blood glucose through crustacean hyperglycaemic hormone $(\mathrm{CHH})$ is under the control from a variety of neurohormones (Fingerman, 1997). Hsieh et al (2006) reports that dopamine, serotonin, norepinephrine, epinephrine and octopamine are all effective in inducing hypergylcemic responses in a variety of crustaceans. Crustacean hyperglycaemic hormone is synthesised and released from the x-organ sinus complex. The release of $\mathrm{CHH}$ has been shown to be promoted through injection with 5HT in a variety of species (Fingerman, 1997) whereas DA can have an inhibitory effect (Sarojini et al 1995). 
306 The evidence suggests as with many of the biological systems that serotonin and dopamine 307 play a counteractive control.

308

Colour within the crustaceans is controlled through a number of neurohormones which act 310 upon chromatophores within the epithelial tissues. A considerable body of research exists that 311 have studied the function of neurohormones on specific group of peptide hormones that can 312 concentrate or disperse the pigments within the chromatophores (Fingerman, 1997). These 313 have been named after the colours of the pigments under their control (e.g. red-pigment 314 dispersing hormone; RGDH) and whether they have concentrating or dispersing properties 315 (e.g. red-pigment concentrating hormone). Serotonin has been shown to influence red316 pigment dispersing hormone whilst dopamine influences red- and black-pigment

317 concentrating hormone. Fingerman (1997 and papers within) report norepinephrine triggers 318 release of black-pigment dispersing hormone but not RGDH. 


\section{Effects of antidepressants in Molluscans and Crustaceans}

\section{a. Mollusca}

Molluscs have been model organisms for the study the effects of released pharmaceuticals on aquatic organisms, because of their abundance, diversity in different aquatic environments, and ecological importance. Since antidepressants exert their effects mainly through serotonergic neurons, and since serotonin receptors have been well studied in molluscs, this group is a logical choice of test organism for such effects. Not surprisingly, fluoxetine ("Prozac") was one of the first SSRI's tested for its effect on aquatic invertebrates since it is commonly detected in wastewater influent, effluent, and in receiving streams. With one exception all of studies of the effects of antidepressants on molluscs have been on the two largest groups, the gastropods and bivalves. Furthermore, with few exceptions, reproductive processes (egg laying, embryo production in gastropods and spawning, larval release, parturition in bivalves) have been the focus of these studies.

\section{i. Gastropods}

In one of the first papers to document an effect of an antidepressant on any mollusc, Couper and Leise (1996) microinjected veliger larvae of the marine gastropod Ilyanassa obsoleta to fluoxetine $(1 \mu \mathrm{M})$. They found that fluoxetine significantly induced larval metamorphosis compared with controls, and at a lower but not significantly different percentage than bath applied serotonin. While their study was cell physiological in nature as opposed to environmental, in that larvae were injected with fluoxetine, it did suggest that externally applied antidepressants could also have salient effects on critical life cycle events in aquatic invertebrates.

Much of the subsequent work on antidepressants and aquatic molluscs employed bivalves as test organisms. But, Nentwig 2007 working on an invasive species, the New Zealand mud snail Potamopyrgus antipodarum found that snails exposed to fluoxetine had significantly reduced embryo production. His 10 percent effect concentration of fluoxetine was $0.81 \mu \mathrm{g} / \mathrm{L}$. While $P$. antipodarum had been used previously as a test organism in aquatic toxicity testing (Duft et al. 2003), this study was the first to use the mud snail as a suitable gastropod for antidepressant testing. Pery et al.(2008) also working with P. antipodarum found that fluoxetine did not effect growth, but did reduce the number of offspring at $69 \mu \mathrm{g} / \mathrm{L}$. Furthermore and in the same laboratory, Gust et al. (2009), again working with $P$. antipodarum found that mud snails exposed to high $(100 \mu \mathrm{g} / \mathrm{L})$ fluoxetine produced significantly fewer embryos or eggs compared with controls. But at low concentrations (3.7 
and $11.1 \mu \mathrm{g} / \mathrm{L}$ ) fluoxetine-exposed snails produced more embryos than the control. They also found a generational effect of fluoxetine on mud snail reproduction. The $\mathrm{F}_{1}$ generation of $P$. antipodarum grew faster and reproduced more slowly than their fluoxetine-exposed parents regardless of concentration. In the same year, Sanchez-Arguello et al. (2009) working with another freshwater gastropod, Physa acuta found that fluoxetine stimulated reproduction at 31.25 and $62.5 \mu \mathrm{g} / \mathrm{L}$ but at the highest concentration $250 \mu \mathrm{g} / \mathrm{L}$ reproduction was inhibited. These results are similar to those of Pery et al. (2009), but at different concentrations and in a different species.

Recently, two studies of antidepressants effects have focused on locomotion in freshwater and marine gastropods. The regulation of gastropod locomotion and ciliary movement by serotonin has been well documented for decades (Audesirk et al., 1979, Sakharov and Salanki 1982). Furthermore, Uhler et al., (2000) found that fluoxetine stimulated cilia-driven rotation in freshwater snail (Physa) embryos. However, up to now, no studies have shown an effect of antidepressants on gastropod locomotion. Fong and Hoy (2012) and Fong and Molnar (2013) found that various antidepressants cause foot detachment from the substrate in freshwater and marine gastropods. Freshwater gastropods, Leptoxis carinata and Stagnicola elodes, were exposed to venlafaxine. This antidepressant was reported to be the most common measured in North American (Metcalfe et al, 2010, Schultz et al. 2010) and European (Styrishave et al. 2011) wastewater treatment plants and receiving streams. Exposure to venlafaxine at an LOEC of $313 \mathrm{pg} / \mathrm{L}$ induced foot detachment from the substrate in L. carinata and $31.3 \mathrm{ng} / \mathrm{L}$ in $S$. elodes. These concentrations are orders of magnitude lower than concentrations in wastewater effluent (Fong and Hoy, 2012).

Fong and Molnar (2013) measured foot detachment from substrate in five species of marine snail from the Pacific and Atlantic coasts of North America exposed to four different antidepressants. They found that trochids (Chlorostoma, Tegula) and turbinids (Lithopoma) were more sensitive to antidepressants than were muricids (Urosalpinx, Nucella). Their lowest LOEC was $43.4 \mu \mathrm{g} / \mathrm{L}$ fluvoxamine on $L$. americanum and $157 \mu \mathrm{g} / \mathrm{L}$ venlafaxine on $C$. funebralis. Foot detachment from the substrate is a potential sub-lethal effect that could result transport to unfavorable habitats and which would be difficult to detect in nature. While the effective concentrations found by Fong and Molnar are higher than environmental concentrations, antidepressants and their sub-lethal effects can accumulate over time (Seiler, 2002) and can be enhanced by the concomitant release of other pharmaceuticals (Silva et al. 2012). 
Because of its importance in bivalve aquaculture protocols, spawning had been shown to be inducible by external application of serotonin and its receptor ligands (Gibbons and Castagna, 1984, Ram et al 1993, Fong et al. 1993b). Fong (1998) tested the effect of the antidepressants fluvoxamine and fluoxetine on spawning in the zebra mussel (Dreissena polymorpha). He found that low concentrations of both antidepressants induced male mussels to spawn when exposed to $1 \mathrm{nM}$ fluvoxamine and to $50 \mathrm{nM}$ fluoxetine. In the same year, Fong et al., (1998) showed that parturition in the freshwater fingernail clam (Sphaerium striatinum) was induced by $10 \mathrm{nM}$ fluvoxamine. Since zebra mussels are a serious aquatic pest species that have spread throughout Europe and are moving rapidly throughout North America, and since fingernail clams are a prominent member of the freshwater benthos worldwide, the finding that low concentrations of antidepressants could induce reproductive processes in them triggered a number of subsequent studies on effects of different antidepressants on aquatic animals.

Over a decade later, Lazzara et al. (2012) exposed zebra mussels to environmentally relevant concentrations of fluoxetine over several days. Gonads of fluoxetine-exposed mussels showed a reduction in both oocytes per follicle and spermatozoa per seminiferous tubule compared with controls at concentrations as low as $20 \mathrm{ng} / \mathrm{L}$. This concentration is even lower than that found to induce spawning by Fong (1998). However, Lazzara et al did not actually observe spawning, but rather noticed differences in gonads between exposed and control mussels, and from this they concluded that zebra mussel spawning may be inducible at even much lower fluoxetine concentrations following exposure for a period of several days.

Working with the marine bivalve Macoma balthica, Honkoop et al. (1999) found that its spawning season could be extended in the laboratory by the combination of temperature shock with $1 \mathrm{mg} / \mathrm{L}$ fluoxetine. Their finding was valuable not only because it was the first to show an effect of an antidepressant on a marine bivalve, but it was also important to bivalve mariculture managers seeking ways to maintain spawning stock for an extended period of time.

Exposure to antidepressants also has an effect on release of larvae and reproductive behaviour the freshwater unionids. Populations of North American unionids have been declining for decades due to habitat loss and alteration, water quality degradation, and competition from exotic species such as zebra mussels (Ricciardi and Rasmussen, 1999). 
425 The additional physiological stressor of antidepressant and other pharmaceutical pollution 426 does not bode well for this threatened and endangered group. Cunha and Machado (2001) 427 induced parturition in Anodonta cygnea. By contrast to Fong's 1998 work, they found that fluoxetine was more potent than fluvoxamine inducing strong release of glochidial larvae at 1 $\mu \mathrm{M}$. Bringolf et al. (2010) measured the concentration of fluoxetine in water, sediment, and mussel tissue downstream from wastewater effluent and in freshwater mussels (Elliptio complanata) living within the sediment. Mussel tissues accumulated fluoxetine (79 ng/L) compared with that measured in water (104-119 ng/L) and in sediment (17.4 ng/L). In 96hour lab tests, mussels exposed to fluoxetine at 300 and $3000 \mu \mathrm{g} / \mathrm{L}$ significantly released nonviable glochidia. Male E. complanata exposed to $3000 \mu \mathrm{g} / \mathrm{L}$ significantly released spermatozeugmata over a 48-hour period. Interestingly, but not surprisingly, exposure to the same fluoxetine concentrations also stimulated lure display behavior in female Lampsilis fasciola and L. cardium. Female Lampsilis spp. have mantle edges modified to resemble small fishes in order to attract larger predatory fishes that act as hosts for glochidia larvae. As host fish approach the mantle "lure" the female releases a cloud of glochidia which then attach to and parasitize the host fish. In addition, Hazelton et al (2013) studied the reproductive behavior and life cycle of three species of $L$. fasciola exposed to fluoxetine. Exposure to fluoxetine $29.3 \mu \mathrm{g} / \mathrm{L}$ significantly increases the probably of lure display compared with controls. The reproductive consequences of this altered behavior is difficult to assess, but increasing the probability of lure displays during times when glochidia are not mature or during a time when host fishes are less likely to be active could have negative effects on overall recruitment.

In the only study to date on the effects of externally applied antidepressants on a cephalopod, Di Poi et al., (2013) measured several learning variables in newborn cuttlefish, Sepia officianlis exposed to 1 and $100 \mathrm{ng} / \mathrm{L}$ fluoxetine. Fluoxetine did not affect feeding motivation, but it did inhibit cuttlefish efficiency at striking prey at $1 \mathrm{ng} / \mathrm{L}$ which is lower than environmental concentrations. Interestingly, at $100 \mathrm{ng} / \mathrm{L}$ fluoxetine, the learning performance of cuttlefish was closer to that of control cuttlefish. Furthermore, memory retention was inhibited by both low and high fluoxetine concentrations. Thus fluoxetine exposure could have serious consequences on feeding behavior at a young age and could possibly affect other behaviors as animals grow. 
To date, despite a considerable body of work using decapod models to investigate the neurobiology of Crustacea, the studies investigating the effects of antidepressants have focussed on more traditional ecotoxicological models such as amphipods and daphniids. The work with amphipods has mainly focused on behaviour whilst the work with daphniids has looked at mortality and reproductive endpoints. De Lange et al. (2006) exposed the freshwater amphipod, Gammarus pulex to a variety of chemicals, including fluoxetine, and measured their activity using the multispecies freshwater biomonitor (MFB). The MFB uses a quadruble impediance conversion technique to record movements of aquatic organisms in a test chamber (Gerhardt et al. 1994). The activity of G. pulex were recorded every 10 minutes for 1.5 hours following a 30 minute acclimation period. The authors recorded a significant decrease in activity at low (10-100ng/L) fluoxetine, but no significant differences from the controls at higher concentrations $(1 \mu \mathrm{g} / \mathrm{L}-1 \mathrm{mg} / \mathrm{L})$. De Lange et al. (2009) re-analysed the previous experiments using multivariate statistical analysis to differentiate patterns in locomotion and ventilation changes. The authors report that recording ventilation can be used to measure signs of stress. The re-analysis revealed that G. pulex in fluoxetine showed increased ventilation at $10-100 \mathrm{ng} / \mathrm{L}$ whilst the higher concentrations were closer to the control.

Guler and Ford (2010) studied the effects of a variety of pharmaceuticals and the hormone serotonin on the preference to lights $v s$ dark choice chambers in the marine/estuarine amphipod Echinogammarus marinus. The authors exposed the amphipods over a period of one, two and three weeks and recorded the preference to light or dark areas and depth, every 30 seconds, over a ten minute period. The authors reported a significant preference of light and negative geotaxis in the amphipods exposed to fluoxetine and serotonin. Interestingly the dose response was linear for serotonin whereas it followed a non-monotonic concentration response for fluoxetine with the lower concentrations (10-100ng/L) differing from the control. E. marinus exposed to 100ng/L fluoxetine spent 5 times more time in lights areas than control animals which prefer dark. The authors highlighted that parasites such as acanthocephalans and trematodes known to induce increased levels of cerebral serotonin also invoke similar behaviours reversing the preference to light and have been demonstrated to increase the likelihood of predation. For example, Perrot-Minnot et al. (2007) studied the predation vulnerability of $G$. pulex infected by the fish acanthocephalan, $P$. tereticollis, both 
in laboratory and field conditions. In field studies, the final host predator (Bullhead fish) had 10 times higher proportions of infected $G$. pulex it its gut than uninfected individuals sampled within the same river. In addition, microcosm experiments showed that uninfected individuals increased the use of refuges in the presence of bullhead predators (Perrot-Minnot et al., 2007). In a similar study, Lagrue et al. (2007) found 26.3-28.3 times higher proportion of infected G. pulex amphipods in the stomach content of one of the definitive hosts of $P$. laevis, the bullhead Cottus gobio. Huber et al (1997) studied the effects of serotonin on aggression in crayfish and found that whilst injection with 5HT made crayfish more aggressive, exposure to fluoxetine had no effect. When fluoxetine was injected in combination with serotonin the aggressive behaviour was reduced compared to serotonin alone leading the authors to suggest that serotonin uptake plays an important role in these behaviour reversals.

Henry et al. (2004) studied the acute and chronic effects of five SSRIs (fluoxetine, fluvoxamine, paroxetine, citralopram and sertraline) on the daphnid, Ceriodaphnia dubia. The 48-h LC50s for the SSRIs ranged from 0.12 to $3.9 \mathrm{mg} / \mathrm{L}$ in terms of increasing toxicity could be ranked as: Citralopram < Fluovoxamine < Paroxatine < Fluoxetine $<$ Sertraline. The authors also observed that SSRIs negatively affect reproduction either through reducing the number of neonates per female or by reducing the number of broods per female. Sertraline and Citalopram were found not to significantly affect the number of broods per female whereas the lowest-observed-effect concentration for the other three could be ranked in increasing toxicity from: Fluvoxamine $(1.466 \mathrm{mg} / \mathrm{L})<$ Fluoxetine $(0.447 \mathrm{mg} / \mathrm{L})<$ Paroxetine $(0.44 \mathrm{mg} / \mathrm{L})$. The Lowest-observed-effect concentration for numbers of neonates per female were, in increasing toxicity, ranked: Citralopram $(4 \mathrm{mg} / \mathrm{L})<$ Fluovoxamine $(1.466 \mathrm{mg} / \mathrm{L})<$ Fluoxetine $(0.447 \mathrm{mg} / \mathrm{L})<$ Paroxatine $(0.44 \mathrm{mg} / \mathrm{L})<$ Sertraline $(0.045 \mathrm{mg} / \mathrm{L})$. The authors noted the different SSRIs differed in their rank effects on spawning from other species (Fong et al. 1998) but noted this maybe down to interspecies differences or the SSRIs acting through different mechanisms.

Christensen et al. (2007) observed in Daphnia magna that the EC50s (immobility) for the same SSRIs ranged from 0.92 to $20 \mathrm{mg} / \mathrm{L}$ and were ranked increasing toxicity: Citralopram < Fluovoxamine < Fluoxetine < Paroxatine < Sertraline; and hence broad agreement of increasing toxicity with Henry et al (2004). The authors also conducted three different binary mixture experiments with the SSRIs Citalopram, Fluoxetine and Sertraline. They found no 
527 evidence synergism or antagonism, however a concentration addition (CA) model best 528 explained the observed data and concluded that because several SSRIs can be found in the 529 environment that mixture effects for these compounds must be included in their risk 530 assessment.

Campos et al. (2012a) investigated offspring production in Daphnia magna following 533 exposure to the SSRIs, fluoxetine $(10,40 \& 80 \mu \mathrm{g} / \mathrm{L})$ and fluvoxamine $(7 \& 30 \mu \mathrm{g} / \mathrm{L})$ and 534 compared clones, life-stages and food rations. In the fluvoxamine exposures juveniles developed earlier and subsequently reproduced earlier relative to controls whereas fluoxetine increased offspring production relative to controls. When individuals were exposed from

537 birth, enhanced offspring production per female was only observed at low and intermediate

538 food rations. The authors suggested that this could be due to the compounds interference with 539 endogenous serotonin which may differ with high vs low food rations. Campos et al (2012b)

540 further tested this hypothesis repeating experiments also with the 5-HT serotonin receptor 541 antagonist cyproheptadine. The authors found that exposure to SSRIs increased juvenile 542 development rate, clutch size, and decreased offspring size at low and intermediate levels of 543 food rations. These results were reversed by the presence of the 5-HT receptor agonist and 544 concluding that the 5-HT receptor was pivotal to the effects of fluvoxamine and fluoxetine. 545 Using a transcriptomic response Campos et al (2013) recently used a 15,000 probe custom 546 made microarray to determine the differential gene expresson of Daphnia magna exposed to 547 SSRIs (fluoxetine $40 \mu \mathrm{g} / \mathrm{L}$ and fluvoxamine $7 \mu \mathrm{g} / \mathrm{L}$ ). Serotonin metabolism, neuronal 548 development processes, carbohydrate and lipid metabolism functions were found to be 549 differentially expressed when annotated against the Drosophila. 


\section{Conclusions/Summary}

In this review we have shown that the capability for antidepressants to disrupt the normal biological systems of two highly abundant and ecologically important invertebrate groups is extensive. Through the interference of neurohormones such as serotonin, dopamine and norepinephrine, for which antidepressants are deliberately designed to modulate; antidepressants have the potential to effect multiple biological processes including reproduction, growth, metabolism, immunity, feeding, locomotion, colour physiology and behaviour.

A body of evidence is building that suggest that antidepressants, at concentrations currently found in surface, waste and groundwaters are sufficient to cause a wide variety of effects (based on laboratory studies). This is despite that fact that reports suggest that these types of drugs only take up $4 \%$ of the known relative proportions of pharmaceuticals detected in the environment (Santos et al. 2010). Whether such effects are occurring within the field are currently unknown and represent an important and challenging question for ecotoxicologists to address. In this review we have highlighted fluoxetine can impact learning and retention efficiencies in cuttlefish between 1-100ng/L (Di Poi et al 20130) induce phototactic responses in amphipods as low as 10ng/L; impact swimming activity in amphipods as low as 1-100ng/L (De Lange et al. 2006; Bossus et al., in review) and induce gonadal aberrations in zebra mussels as low as $20 \mathrm{ng} / \mathrm{L}$. Studies with another antidepressants, fluvoxamine (SSRI) have induce spawning in zebra mussel at $~ 318 \mathrm{ng} / \mathrm{L}$ (Fong, 1998) and exposure to venlafaxine (SNRI) causes foot detachment as low as $313 \mathrm{pg} / \mathrm{L}$ and $31.3 \mathrm{ng} / \mathrm{L}$ from the substrate in L. carinata in S. elodes respectively (Fong and Hoy, 2012; Fong and Molnar, 2013). Further effects on reproductive output in terms of frequency of broods, offspring production, gamete release and gene expression have been revealed in the ug/L concentrations.

In reviewing the current literature, a number of interesting research questions have been highlighted: An increasing number of studies are finding biological effects at lower concentrations but not at higher concentrations. For example, Sanchez-Arguello et al., 2009 found a stimulation of reproduction in the snail, Physa acuta at lower fluoxetine concentrations and got the opposite effect at higher concentrations. Conners et al (2009) found that Xenopus tadpoles in low and moderate concentrations of sertraline $(0.1$ and 1.0 $\mu \mathrm{g} / \mathrm{L})$ and moderate concentrations of fluoxetine $(1.0 \mu \mathrm{g} / \mathrm{L})$ metamorphosed sooner whereas 
those tadpoles in high concentrations $(10.0 \mu \mathrm{g} / \mathrm{L})$ were most similar to controls. Guler and Ford (2010) observed stronger phototaxis responses in the amphipod E. marinus at low (10$100 \mathrm{ng} / \mathrm{L}$ ) concentrations of fluoxetine whereas no significant differences from the controls at higher concentrations (1000 ng/L). Di Poi et al (2012) found that whilst 1ng/L fluoxetine influenced learning in the cuttlefish, 100ng/L did not, but did significantly influence the retention of memory. Some of the studies mentioned in this review only conducted experiments at higher concentrations $(\mu \mathrm{g}-\mathrm{mg} / \mathrm{L})$. Considering the non-monotonic concentration curves revealed by these studies (De Lange et al 2006; Sanchez-Arguello et al., 2009; Conners et al. 2009; Guler and Ford, 2010; Di Poi et al 2012); would the endpoints measured revealed greater effects at lower concentrations? This suggests that in designing future experiments, ecotoxicologists should be mindful of the range of concentrations used and will certainly add to the debate about hormesis effects in toxicology.

Many of the studies were also conducted over relatively short time periods, and thus bearing in mind the role serotonin and dopamine play in maturation and reproduction; would antidepressants impact aquatic organisms over long exposure periods and at critical stages in their development? These neurohormones play important roles in biological systems not yet currently tested as endpoints in antidepressant ecotoxicity studies. For example, do antidepressants effect aquatic organisms in ways that impact their immune systems leaving them more susceptible to pathogens and parasites? Do antidepressants impact an organism's ability to change colour and remain cryptic in their environment? Can antidepressants subtly effect the way they interact within their populations through e.g. aggression towards conspecifics or competition for mates?

The evolution of the neuroendocrine systems throughout the animal kingdom are 'relatively' well conserved compared to the reproductive systems. For example, those genes under considerable sexual selection within the reproductive systems undergo rapid change (Ellegren and Parsch, 2007) and the hormonal control of reproductive systems of invertebrate groups vary considerably (Crane and Tattersfield 1999). Consequently this made making interspecies biomarker development both within and between the invertebrate phyla more difficult. This has hampered the assessment of reproductive endocrine disruption in many invertebrate groups due to a lack of knowledge of general endocrinology and molecular biology required to determine mechanisms of toxicology. The neuroendocrine systems of invertebrates have considerably more depth of knowledge, especially considering that many 
invertebrate groups have been used as model organisms to study the nervous systems in general. The mechanisms by which chemical and electrical signals are mediated along and across neural junctions are relatively well conserved throughout the animal kingdom. As a result, there are now numerous methods for which to measure and visualise the neurological activity within tissues and there are a variety of standard chemical biomarkers for the measurement of neurohormones. Through the advent of affordable genomic and transcriptomic sequencing we also have the ability to measure entire gene pathways in organisms which in previous genomic data did not exist. This should enable us to determine the molecular unpinning of specific or generic aberrant behaviour such as phototaxis or general activity caused by antidepressant exposure. However, the difficulties will arise, as is often the case, through the interpretation of genomic through to behavioural data in the risk assessment of these chemicals within the natural populations. For example, can we answer what might an altered behaviour below some sewage outfall might be extrapolated to in terms of loss of feeding, increased predation and mate finding? Clotfelter et al. (2004) highlighted the need for a better dialogue between ecotoxicologists and behavioural ecologists to understand these problems. Can we also differentiate those impacts of antidepressants from the myriad of other pharmaceuticals in wastewater effluent?; do other environmental contaminants such as industrial chemicals have the ability to interfere with the synthesis, breakdown and action of neurohormones? and finally do antidepressants act synergistically, additively or antagonistically in mixtures with each other drug or other environmental pollutants. Whilst we have outlined quite a large number of unknowns we have come a long way since the first studies on antidepressants. There does appear to be compelling evidence that environmental levels of antidepressants have the ability to impact invertebrate populations.

\section{Acknowledgements}

ATF would like to acknowledge the following awarding bodies for supporting this research: The EU INTERREG programme entitled Peptide Research Network of Excellence (PeReNE) and the UK Natural Environmental Research Council (NERC; NE/G004587/1).

\section{References}


Aiello, E.,1970. Nervous and chemical stimulation of gill cilia in bivalve mollusks. Physiological Zoology 43, 60-70

Audesirk, G., McCaman, R.E., Willows, A.O.D., 1979. The role of serotonin in the control of pedal ciliary activity by identified neurons in Tritonia diomedea. Comparative Biochemistry Physiology C 62, 87-91.

Bauer, A., Haine, E. R., Perrot-Minnot, M. J., \& Rigaud, T., 2005. The acanthocephalan parasite Polymorphus minutus alters the geotactic and clinging behaviours of two sympatric amphipod hosts: the native Gammarus pulex and the invasive Gammarus roeseli. Journal of Zoology 267(1), 39-43.

Benotti, M.J., Brownawell, B.J., 2007. Distributions of pharmaceuticals in an urban estuary during both dry- and wet-weather conditions. Environmental Science Technology 41, 5795-5802.

Bethel, W.M. and Holmes, J.C., 1973. Altered evasive behaviour and responses to light in amphipods harbouring acanthocephalan cystacanths. Journal of Parasitology 59, 945956.

Birmingham J.T., Tauck, D.L., 2003. Neuromodulation in invertebrate sensory systems: from biophysics to behaviour Journal Experimental Biology 206, 3541-3546.

Boxall, A.B.A., Rudd, M.A., Brooks, B.W., Caldwell, D.J., Choi, K., Hickmann, S., Innes, E., Ostagpyk, K., Staveley, J.P., Verslycke, T., Ankley, G.T., Beazley, K.F., Belanger, J.P., Carriquiriborde, P., Coors, A., DeLeo, P.C., Dyer, S.D., Ericson, J.F., Gagne, F., Giesy, J.P., Gouin, T., Hallstrom, L., Karlsson, M.V., Larsson, D.G.J., Lazorchak, J.M., Mastrocco, F., McLaughlin, A., McMaster, M.E., Meyerhoff, R.D., Moore, R., Parrott, J.L., Snape, J.R., Murray-Smith, R., Servos, M.R., Sibley, P.K., Straub, J.O., Szabo, N.D., Topp, E., Tetreault, G.R., Trudeau, V.L., Van Der Kraak, G. 2012. Pharmaceuticals and personal care products in the environment: What are the big questions? Environmental Health Perspectives 120, 1221-1229.

Brausch, J.M., Connors, K.A., Brooks, B.W., Rand, G.M., 2012. Human pharmaceuticals in the aquatic environment: A review of recent toxicological studies and considerations for toxicity testing. Reviews Environmental Contamination and Toxicology 218, 1-99. 
Bringolf, R.B., Heltsley, R.M., Newton, T.J., Eads, C.B., Fraley, S.J., Shea, D., Cope, W.G., 2010. Environmental occurrence and reproductive effects of the pharmaceutical fluoxetine in native freshwater mussels. Environmental Toxicology Chemistry 29(6), 1311-1318.

Brooks, B.W., Huggett, D.B., 2012. Human Pharmaceuticals in the Environment. Springer, New York.

Calisto, V., Esteves, V.I., 2009. Psychiatric pharmaceuticals in the environment. Chemosphere 77, 1257-1274.

Campos, B., Garcia-Reyero, N., Rivetti, C., Escalon, L., Habib, T., Tauler, R., Barata, C., 2013. Identification of metabolic pathways in Daphnia magna explaining hormetic effects of selective serotonin reuptake inhibitors and 4-nonylphenol using transcriptomic and phenotypic responses. Environmental science \& technology

Campos, B., Piña, B., \& Barata C, C., 2012. Mechanisms of action of selective serotonin reuptake inhibitors in Daphnia magna. Environmental science \& technology 46(5), 2943-2950.

Cézilly, F., Grégoire, A., Bertin, A., 2000. Conflict between co-occurring manipulative parasites? An experimental study of the joint influence of two acanthocephalan parasites on the behaviour of Gammarus pulex. Parasitology 120(6), 625-630.

Chen, Y. N., Fan, H. F., Hsieh, S. L., Kuo, C. M., 2003. Physiological involvement of DA in ovarian development of the freshwater giant prawn, Macrobrachium rosenbergii Aquaculture 228(1), 383-395.

Chen, M., Ohman, K., Metcalfe, C., Ikonomou, M.G., Amatya, P., Wilson, J., 2006. Pharmaceuticals and endocrine disruptors in wastewater treatment effluent and in the water supply system of Calgary, Alberta, Canada. Water Quality Research Journal Canada 41(4), 351-364.

Cheng, W., Chieu, H. T., Ho, M. C., Chen, J. C., 2006. Noradrenaline modulates the immunity of white shrimp Litopenaeus vannamei Fish \& Shellfish Immunology, 21(1), 11-19.

Cheng, W., Chieu, H. T., Tsai, C. H., Chen, J. C., 2005. Effects of dopamine on the immunity of white shrimp Litopenaeus vannamei. Fish \& shellfish immunology 19(4), 375385. 
Choong, A.M.F., Teo, S.L-M., Leow, J.L., Koh, H.L., Ho, P.C.L., 2006. A preliminary ecotoxicity study of pharmaceuticals in the marine environment. Journal Toxicology Environmental Health (A) 69, 1959-1970.

Christensen, A. M., Faaborg-Andersen, S., Flemming, I., Baun, A., 2007. Mixture and single-substance toxicity of selective serotonin reuptake inhibitors toward algae and crustaceans. Environmental Toxicology and Chemistry 26(1), 85-91.

Clotfelter, E.D., Bell, A.M., Levering, K.R., 2004. The role of animal behaviour in the study of endocrine-disrupting chemicals. Animal Behaviour 68, 665-676.

Conners, D. E., Rogers, E. D., Armbrust, K. L., Kwon, J. W., Black, M. C., 2009. Growth and development of tadpoles (Xenopus laevis) exposed to selective serotonin reuptake inhibitors, fluoxetine and sertraline, throughout metamorphosis. Environmental Toxicology and Chemistry, 28(12), 2671-2676.

Couper, J.M., Leise, E.M., 1996. Serotonin injections induce metamorphosis in larvae of the gastropod mollusc Ilyanassa obsoleta. Biological Bulletin 191, 178-186.

Crane, M., Tattersfield, L. J. (Eds.). 1999. Endocrine disruption in invertebrates: endocrinology, testing, and assessment. Pensacola: SETAC Press. 303pp

Croll, R.P., Van Minnen, J., Kits, K.S., Smid, A.B., 1991. APGWamide: molecular, histological and physiological examination of he novel neuropeptide involved with reproduction in the snail, Lymnaea stagnalis. In: K.S. Kits, H.H. Boer, J. Joose (Eds.), Molluscan Neurobiology, Amsterdam, North-Holland.

Cunha, E.M., Machado, J., 2001. Parturition in Anodonta cygnea induced by selective serotonin reuptake inhibitors (SSRIs). Canadian Journal Zoology 79(1), 95-100.

Daughton, C.G., Ternes, T.A., 1999. Pharmaceuticals and personal care products in the environment: Agents of subtle change? Environmental Health Perspectives 107 (Supplement 6), 907-938.

Daughton, C.G., Brooks, B.W., 2011. Activte pharmaceutical ingredients and aquatic organisms. In: Beyer, N. and Meador, J. (Eds.), Environmental Contaminants in Biota: Interpreting tissue Concentrations. Taylor and Francis, Philadelphia.

Dayan, P., Huys, Q.J.M., 2009. Serotonin in affective control. Annual Review Neuroscience $32,95-126$. 
De Lange, H. J., Noordoven, W., Murk, A. J., Lürling, M. F. L. L. W., \& Peeters, E. T. H. M. (2006). Behavioural responses of Gammarus pulex (Crustacea, Amphipoda) to low concentrations of pharmaceuticals. Aquatic Toxicology 78(3), 209-216.

De Lange, H. J., Peeters, E. T., \& Lürling, M. F. L. L. W., 2009. Changes in ventilation and locomotion of Gammarus pulex (Crustacea, Amphipoda) in response to low concentrations of pharmaceuticals. Human and Ecological Risk Assessment 15(1), 111-120.

Deliagina, T.G., Orlovsky, G.N., 1990. Control of locomotion in the freshwater snail Planorbis corneus. II. Differential control of various zones of the ciliated epithelium. Journal Experimental Biology 152, 405-423.

Diefenbach, T.J., Koss, R., Goldberg, J.I., 1998. Early development of an identified serotonergic neuron in Helisoma trivolvis embryos: Serotonin expression, deexpression, and uptake. Developmental Neurobiology 34(4), 361-376.

Di Poi, C., Darmaillacq, A-S, Dickel, L., Boulouard, M., Bellanger, C., 2013. Effects of perinatal exposure to waterborne fluoxetine on memory processing in the cuttlefish Sepia officinalis. Aquatic Toxicology 132-133, 84-91.

Diwan, A. D. (2005). Current progress in shrimp endocrinology—a review. Indian Journal Experimental Biology 43(3), 209-223.

Doernberg, S. B., Cromarty, S. I., Heinrich, R., Beltz, B. S., Kravitz, E. A., 2001. Agonistic behavior in naive juvenile lobsters depleted of serotonin by 5, 7-dihydroxytryptamine. Journal of Comparative Physiology A 187(2), 91-103.

Duft, M., Schulte-Oehlmann, U., Tillmann, M., Markert, B., Oehlmann, J., 2003. Toxicity of triphenyltin and tributyltin to the freshwater mudsnail Potamopyrgus antipodarum in a new sediment biotest. Environmental Toxicology Chemistry 22,145-152.

Ellegren H, Parsch, J., 2007. The evolution of sex-biased genes and sex-biased gene expression. Nat Rev Genet 8: 689-698.

Filla A., Hiripi, L., Elekes,K., 2009. Role of aminergic (serotonin and dopamine) systems in the embryogenesis and different embryonic behaviors of the pond snail, Lymnaea stagnalis. Comparative Biochemistry Physiology 149C, 73-82.

Fingerman, M., 1987. The endocrine mechanisms of crustaceans. Journal of crustacean biology 7(1), 1-24. 
Fingerman, M., 1997. Crustacean endocrinology: a retrospective, prospective, and introspective analysis. Physiological Zoology 257-269.

Fingerman, M. (1997). Roles of neurotransmitters in regulating reproductive hormone release and gonadal maturation in decapod crustaceans. Invertebrate Reproduction \& Development 31(1-3), 47-54.

Fingerman, M., Hanumante, M. M., Fingerman, S. W., Reinschmidt, D. C., 1981. Effects of norepinephrine and norepinephrine agonists and antagonists on the melanophores of the fiddler crab Uca pugilator. Journal of Crustacean Biology, 16-27.

Fong, P.P., 1998. Zebra mussel spawning is induced in low concentrations of putative serotonin reuptake inhibitors. Biological Bulletin 194, 143-149.

Fong, P.P., Warner, M., 1995. Serotonin-induced parturition in the fingernail clam Sphaerium (Musculium) transversum (Say). Journal Experimental Zoology 272, 163-166.

Fong, P.P., Hoy, C.M., 2012. Antidepressants (venlafaxine and citalopram) cause foot detachment from the substrate in freshwater snails at environmentally relevant concentrations. Marine Freshwater Behaviour Physiology 45(2), 145-153.

Fong, P.P., Molnar, N., 2013. Antidepressants cause foot detachment from substrate in five species of marine snail. Marine Environmental Research 84, 24-30.

Fong, P.P., Noordhuis, R., Ram, J.L., 1993a. Dopamine reduces intensity of serotonininduced spawning in the zebra mussel Dreissena polymorpha (Pallas). Journal Experimental Zoology 266, 79-83.

Fong, P.P., Wall, D.M., Ram, J.L., 1993b. Characterization of serotonin receptors in the regulation of spawning in the zebra mussel Dreissena polymorpha (Pallas). Journal Experimental Zoology 267, 475-482.

Fong, P.P., Kyozuka, K., Abdelghani, H., Hardege, J.D., Ram, J.L., 1994. In vivo and in vitro induction of germinal vesicle breakdown in a freshwater bivalve, the zebra mussel Dreissena polymorpha (Pallas). Journal Experimental Zoology 269, 467-474.

Fong, P.P., Huminski, P.T., D’Urso, L.M., 1998. Induction and potentiation of parturition in fingernail clams (Sphaerium striatinum) by selective serotonin re-uptake inhibitors (SSRIs). Journal Experimental Zoology 280, 260-264.

Gardiner, D.B., Silverman, H., Dietz, T.H., 1991. Musculature associated with the water canals in freshwater mussels and response to monoamines in vitro. Biological Bulletin 180(3), 453-465.

Gibbons, M.C., Castagna, M., 1984. Serotonin as an inducer of spawning in six bivalve species. Aquaculture 40, 189-191. 
Gosselin, R.E., 1961. The cilioexcitatory activity of serotonin. Journal Cellular Comparative Physiology 58(1), 17-25.

Guerrier, P., Durocher, Y., Gobet, I., Leclerc, C., Moreau, M., 1996. Reception and transduction of the serotonin signal responsible for oocyte meiosis reinitiation in bivalves. Invertebrate Reproduction Development 30, 39-45.

Guler, Y., Ford A.F., 2010. Anti-depressants make amphipods see the light. Aquatic Toxicology 99, 397-404.

Gust, M., Buronfosse, T., Giamberini, L., Ramil, M., Mons, R., Garric, J., 2009. Effects of fluoxetine on the reproduction of two prosobranch mollusks: Potamopyrgus antipodarum and Valvata piscinalis. Environmental Pollution 157, 423-429.

Hazelton, P.D., Cope, W.G., Mosher, S., Pandolfo, T.J., Belden, J.B., Barnhart, M.C., Brongolf, R.B., 2013. Fluoxetine alters adult freshwater mussel behaviour and larval metamorphosis. Science Total Environment 445, 94-100.

Henry, T. B., Kwon, J. W., Armbrust, K. L., Black, M. C., 2004. Acute and chronic toxicity of five selective serotonin reuptake inhibitors in Ceriodaphnia dubia. Environmental toxicology and chemistry 23(9), 2229-2233.

Hignite, C., Azarnoff, D.L., 1977. Drugs and drug metabolites as environmental contaminants: chlorophenoxyisobutyrate and salicylic acid in sewage water effluent. Life Sciences20, 337-342.

Hirai, S., Kishimoto, T., Kadam, A.L., Kanatani, H., Koide, S.S., 1988. Induction of spawning and oocyte maturation by 5 -hydroxytryptamine in the surf clam. Journal Experimental Zoology 245, 318-321.

Honkoop, P.J.C., Luttikhuizen, P.C., Piersma, T., 1999. Experimentally extending the spawning season of a marine bivalve using temperature change and fluoxetine as synergistic triggers. Marine Ecology Progress Series 180, 297-300.

Hsieh, S. L., Chen, S. M., Yang, Y. H., Kuo, C. M., 2006. Involvement of norepinephrine in the hyperglycemic responses of the freshwater giant prawn, Macrobrachium rosenbergii, under cold shock. Comparative Biochemistry and Physiology-Part A: Molecular \& Integrative Physiology 143(2), 254-263.

Huber, R., Delago, A., 1998. Serotonin alters decisions to withdraw in fighting crayfish, Astacus astacus: the motivational concept revisited. Journal of Comparative Physiology 182A, 573-582. 
Huber, R., Smith, K., Delago, A., Isaksson, K., Kravitz, E. A., 1997. Serotonin and aggressive motivation in crustaceans: altering the decision to retreat. Proceedings of the National Academy of Sciences 94(11), 5939-5942.

Huberman, A., 2000. Shrimp endocrinology. A review. Aquaculture 191(1), 191-208.

Jones-Lepp, T.L., Stevens, R. 2007. Pharmaceuticals and personal care products in biosolids/sewage sludge: the interface between analytical chemistry and regulation. Analytical Bioanalytical Chemistry 387, 1173-1183.

Kadam, A.L., Koide, S.S., 1989. Serotonin analogs and Spisula oocyte maturation. Invertebrate Reproduction Development 17, 33-37.

Kolpin, D.W., Furlong, E.T., Meyer, M.T., Thurman, E.M., Zaugg, S.D., Barber, L.B., Buxton, H.T., 2002. Pharmaceuticals, hormones, and other organic wastewater contaminants in U.S. streams, 1999-2000: A national reconnaissance. Environmental Science Technology 36, 1202-1211.

Krantic, S., Dube, F., Quiron, R., Guerrier, P., 1991. Pharmacology of the serotonin-induced meiosis reinitiation in Spisula solidissima oocytes. Developmental Biology 146, 491498.

Kulkarni, G.K., Nagabhushanam, R, Amadldoss, G., Jaiswal, R.G., Fingerman, M., 1992. In vivo stimulation of ovarian development in the red swamp crayfish, Procambarus clarkii (Girard), by 5-hydroxytryptamine. Invertebrate Reproduction Development $21,231-240$.

Kummerer, K., 2008. Pharmaceuticals in the Environment: Sources, fate, effects, and risks. Springer, New York.

Lagrue, C., Kaldonski, N., Perrot-Minnot, M. J., Motreuil, S., Bollache, L., 2007. Modification of hosts' behaviour by a parasite: filed evidence of adaptive manipulation Ecology 88, 2839-2847.

Lajeunesse, A., Gagnon, C., Sauve, S., 2008. Determination of basic antidepressants and their $\mathrm{N}$-desmethyl metabolites in raw sewage and wastewater using solid-phase extraction and liquid chromatography-tandem mass spectrometry. Analytical Chemistry 80, $5325-5333$. 
Lazzara, R., Blazquez, M., Porte, C., Barata, C., 2012. Low environmental levels of fluoxetine induce spawning and changes in endogenous estradiol levels in the zebra mussel Dreissena polymorpha. Aquatic Toxicology 106-107, 123-130.

Lewis, S.L., Lyons, D.E., Meekins, T.L., Newcomb, J.M., 2011. Serotonin influences locomotion in the nudibranch mollusc Melibe leonine. Biological Bulletin 220(3), 155-160.

Li, J. T., Lee, P. P., Chen, O. C., Cheng, W., Kuo, C. M., 2005. Dopamine depresses the immune ability and increases susceptibility to Lactococcus garvieae in the freshwater giant prawn, Macrobrachium rosenbergii. Fish \& Shellfish Immunology 19(3), 269280.

Madureira, T.V., Barreiro, J.C., Rocha, M.J., Rocha, E., Cass, Q.B., Tiritan, M.E., 2010. Spatiotemporal distribution of pharmaceuticals in the Douro River estuary (Portugal). Science Total Environment 408, 5513-5520.

Manger, P., Li, J., Christensen, B.M., Yoshino, T.P., 1996. Biogenic monoamines in the freshwater snail, Biomphalaria glabrata: Influence of infection by the human blood fluke, Schistosoma mansoni. Comparative Biochemistry Physiology 114A, 227-234.

Matsutani, T., Nomura, T., 1982. Induction of spawning by serotonin in the scallop Patinopectin yessoensis (Jay). Marine Biology Letters 3, 353-358.

McPhee, M.J., Wilkens, J.L., 1989. Serotonin, but not dopamine or octopamine, modifies locmotor and phototaxic behaviour of the crab, Carcinus maenas. Canadian Journal of Zoology 67, 391-393.

Meechonkit, P., Asuvapongpatana, S., Jumromn, W., Kovitvadhi, U., Weerachatyanukul, W., 2012. Sexual differences in serotonin distribution and induction of synchronous larval release by serotonin in the freshwater mussel Hyriopsis bialatus. Journal Molluscan Studies 76(3), 267-274.

Metcalfe, C.D., Chu, S., Judt, C., Li, H., Oakes, K.D., Servos, M.R., Andrews, D.M., 2010. Antidepressants and their metabolites in municipal wastewater, and downstream exposure in an urban watershed. Environmental Toxicology Chemisty 29(1), 79-89.

Muschamp, J.W., Fong, P.P., 2001. Effects of the serotonin receptor ligand methiothepin on reproductive behaviour of the freshwater snail Biomphalaria glabrata: Reduction of egg laying and induction of penile erection. Journal Experimental Zoology 289, 202207.

Nentwig, G., 2007. Effects of pharmaceuticals on aquatic invertebrates. Part II: The antidepressant drug fluoxetine. Archives Environmental Contamination Toxicology 
$52,163-170$.

Osada, M., Nomura, T., 1989. Estrogen effect on the seasonal levels of catecholamines in the scallop Patinopecten yessoensis. Comparative Biochemistry Physiology 93C, 349353.

Osanai, K., Kuraishi, R., 1988. Response of oocytes to meiosis-inducing agents in pelecypods. Bulletin Marine Biological Station Asamushi 18, 45-56.

Pait, A.S., Warner, R.A., Hartwell, S.I., Nelson, J.O., Pacheco, P.A., Mason, A.L., 2006. Human use pharmaceuticals in the estuarine environment: A Survey of the Chesapeake Bay, Biscayne Bay and Gulf of the Farallones. NOS NCCOS 7. Silver Spring, MD. NOAA/NOS/NCCOS/Center for Coastal Monitoring and Assessment. 21pp.

Pal, A., Gin, K.Y-H, Lin, A. Y-C, Reinhard, M. 2010. Impacts of emerging organic contaminants on freshwater resources: Review of recent occurrences, sources, fate and effects. Science Total Environment 408 6062-6069.

Pasztor, V. M., MacMillan, D. L., 1990. The actions of proctolin, octopamine and serotonin on crustacean proprioceptors show species and neurone specificity. Journal of Experimental Biology 152(1), 485-504.

Pavlova, G.A., 2001. Effects of serotonin, dopamine and ergometrine on locomotion in the pulmonate mollusc Helix lucorum. Journal Experimental Biology 204, 1625-1633.

Perrot-Minnot, M. J., Dion, E., Cézilly, F., 2013. Modulatory effects of the serotonergic and histaminergic systems on reaction to light in the crustacean Gammarus pulex. Neuropharmacology.

Pery, A.R.R., Gust, M., Vollat, B., Mons, R., Ramil, M., Fink, G., Ternes, T., Garric, J., 2008. Fluoxetine effects assessment on the life cycle of aquatic invertebrates. Chemosphere 73, 300-304.

Ram, J.L., Fong, P., Croll, R.P., Nichols, S.J., Wall, D., 1992. The zebra mussel (Dreissena polymorpha), a new pest in North America: reproductive mechanisms as possible targets of control strategies. Invertebrate Reproduction Development 22, 77-86. 
Ram, J.L., Crawford, G.W., Walker, J.U., Mojares, J.J., Patel, N., Fong, P.P., Kyozuka, K., 1993. Spawning in the zebra mussel (Dreissena polymorpha): Activation by internal or external application of serotonin. Journal Experimental Zoology 265, 587-598.

Ram, J.L., Moore, D., Putchakayala, S., Paredes, A.A., Ma, D., Croll, R.P., 1999. Serotonergic responses of the siphons and adjacent mantle tissue of the zebra mussel, Dreissna polymorpha. Comparative Biochemistry Physiology (C) 124, 211-220.

Rao, K. R., Fingerman, M., 1983. Regulation of release and mode of action of crustacean chromatophorotropins. American Zoologist 23(3), 517-527.

Ricciardi, A., Rasussen, J.B., 1999. Extinction rates of North American Freshwater Fauna. Conservation Biology 13(5), 1220-1222.

Richardson, M.L., Bowron, J.M., 1985. The fate of pharmaceutical chemicals in the aquatic environment. Journal Pharmacy Pharmacology 37, 1-12.

Roberts, P.H., Thomas, K.V., 2006. The occurrence of selected pharmaceuticals in wastewater effluent and surface waters of the lower Tyne catchment. Science Total Environment 356, 143-153.

Saimi, Y., Murakami, A., Takahashi, K., 1983. Electrophysiological correlates of nervous control of ciliary arrest response in the gill epithelial cells of Mytilus. Comparative Biochemistry Physiology 74A, 499-506.

Sakharov, D.A., Salanki, J.,1982. Effects of dopamine antagonists on snail locomotion. Experientia 38, 1090-1091.

Sánchez-Argüello, P., Fernández, C.,Tarazona, J. V., 2009. Assessing the effects of fluoxetine on Physa acuta (Gastropoda, Pulmonata) and Chironomus riparius (Insecta, Diptera) using a two-species water-sediment test. Science of the Total Environment, 407(6), 1937-1946.

Santos, L.H.M.L.M., Araujo, A.N., Fachini, A., Pena, A., Delerue-Matos, C., Montenegro, M.C.B.S.M., 2010. Ecotoxicological aspects related to the presence of pharmaceuticals in the aquatic environment. Journal Hazardous Materials 175, 45-95.

Sarojini, R., Nagabhushanam, R., Fingerman, M., 1993. In vivo evaluation of 5hydroxytryptamine stimulation of the testis in the fiddler crab, Uca pugilator: a 
presumed action on the neuroendocrine system. Comparative Biochemistry and Physiology 106C, 321-325.

Sarojini, R., Nagabhushanam, R., Fingerman, M., 1995. Dopaminergic and enkephalinergic involvement in the regulation of blood glucose in the red swamp crayfish, Procambarus clarkii. General and comparative endocrinology 97(1), 160-170.

Sarojini, R., Nagabhushanam, R., Fingerman, M., 1995. Mode of action of the neurotransmitter 5-hydroxytryptamine in stimulating ovarian maturation in the red swamp crayfish, Procambarus clarkii: An in vivo and in vitro study. Journal of Experimental Zoology 271(5), 395-400.

Sarojini, R., Nagabhushanam, R., Devi, M., Fingerman, M., 1995. Dopaminergic inhibition of 5-hydroxytryptamine-stimulated testicular maturation in the fiddler crab, Uca pugilator. Comparative Biochemistry and Physiology Part C: Pharmacology, Toxicology and Endocrinology 111(2), 287-292.

Schultz, M.M., Furlong, E.T., 2008. Trace analysis of antidepressant pharmaceuticals and their select degradates in aquatic matrixes by LC/ESI/MS/MS. Analytical Chemistry 80, 1756-1762.

Schultz, M.M., Furlong, E.T., Kolpin, D.W., Werner, S.L., Schoenfuss, H.L., Barber, L.B., Blazer, V.S., Norris, D.O., Vajda, A.M., 2010. Antidepressant pharmaceuticals in two U.S. effluent- impacted streams: occurrence and fate in water and sediment, and selective uptake in fish neural tissue. Environmental Science Technology 44, 19181925.

Seiler, J.P., 2002. Pharmacodynamic activity of drugs and ecotoxicology-can the two be connected? Toxicology Letters 131, 105-115.

Shartau, R., Tam, R., Spencer, P., Goldberg, J.I., 2010. Serotonin prolongs survival of encapsulated pond snail embryos exposed to long-term anoxia. Journal Experimental Biology 213, 1529-1535. 
Silva, L.J.G., Lino, C.M., Meisel, L.M., Pena, A., 2012. Selective serotonin re-uptake inhibitors (SSRIs) in the aquatic environment: an ecopharmacovigilance approach. Science Total Environment 437, 185-195.

Sneddon, L. U., Taylor, A. C., Huntingford, F. A., Watson, D. G., 2000. Agonistic behaviour and biogenic amines in shore crabs Carcinus maenas. Journal of Experimental Biology 203(3), 537-545.

Styrishave, B., Halling-Sorensen, B., Ingerslev, F., 2011. Environmental risk assessment of three selective serotonin reuptake inhibitors in the aquatic environment: A case study including a cocktail scenario. Environmental Toxicology Chemistry 30(1), 254-261.

Sugamori, K.S., Sunahara, R.K., Guan, H., Bulloch, A.G., Tensen, C.P., Seeman, P., Niznik, H.B., Van Tol, H.H.M., 1993. Serotonin receptor cDNA cloned from Lymnaea stagnalis. Proceedings National Academy Sciences USA 90, 11-15.

Syed, N.I., Winlow, W., 1989. Morphology and electrophysiology of neurons innervating the ciliated locomotor epithelium in Lymnaea stagnalis (L.). Comparative Biochemistry Physiology (A) 93(3), 633-644.

Tain, L., Perrot-Minnot, M. J., Cézilly, F., 2006. Altered host behaviour and brain serotonergic activity caused by acanthocephalans: evidence for specificity. Proceedings of the Royal Society B: Biological Sciences 273(1605), 3039-3045.

Tangvuthipong, P., Damrongphol, P., 2006. 5-Hydroxytryptamine enhances larval development of the giant freshwater prawn, Macrobrachium rosenbergii. Aquaculture 251(2), 567-572.

Thomas, K.V.,Hilton, M.J., 2004. The occurrence of selected human pharmaceutical compounds in UK estuaries. Marine Pollution Bulletin 49, 436-444.

Tsyganov, V.V, Sakharov, D.A., 2000. Locomotor rhythms in the pond snail Lymnaea stagnalis: site of origin and neurotransmitter requirements. Acta Biologica Hungarica 51, 189-195. 
Uhler, G.C., Huminski, P.T., Les, F.T., Fong, P.P., 2000. Cilia-driven rotational behaviour in gastropod (Physa elliptica) embryos induced by serotonin and putative serotonin reuptake inhibitors (SSRIs). Journal Experimental Zoology 286, 414-421.

Vaca, A. A., Alfaro, J., 2000. Ovarian maturation and spawning in the white shrimp, Penaeus vannamei, by serotonin injection. Aquaculture 182(3), 373-385.

Vasskog, T., Berger, U., Samuelsen, P.-J., Kallenborn, R., Jensen, E., 2006. Selective serotonin reuptake inhibitors in sewage influents and effuents from Tromso, Norway. Journal Chromatography (A) 1115, 187-195.

Weiger, W.A., 1997. Serotonergic modulation of behaviour: a phylogenetic overview. Biological Reviews Cambridge Philosophical Society 72, 61-95.

Weston, J.J., Huggett, D.B., Rimoldi, J., Foran, C.M., Slattery, M., 2001. Determination of fluoxetine ("Prozac") and norfluoxetine in the aquatic environment. Annual Meeting of the Society of Environmental Toxicology and Chemistry, Baltimore, MD.

Wu, W.H., Cooper, R.L., 2012. Serotonin and synaptic transmission at invertebrate neuromuscular junctions. Experimental Neurobiology 21(3), 101-112.

Wongprasert, K., Asuvapongpatana, S., Poltana, P., Tiensuwan, M., \& Withyachumnarnkul, B., 2006. Serotonin stimulates ovarian maturation and spawning in the black tiger shrimp Penaeus monodon. Aquaculture 261(4), 1447-1454. 